\title{
Investigating Municipal Procurement Challenges in South Africa: A Qualitative Study
}

David R.I. Pooe, University of Johannesburg, South Africa

Chengedzai Mafini, Vaal University of Technology, South Africa

Donna Tsakani Makhubele, Vaal University of Technology, South Africa

\begin{abstract}
This study explored procurement challenges faced by municipalities in South Africa. A qualitative approach was adopted in which semi-structured interviews were employed to elicit information regarding procurement related challenges encountered by municipalities in South Africa. The respondents consisted of ten individuals who were employed as supply chain managers in different municipalities located in Gauteng Province. The findings of the study show that despite the existent policies and support strategies, municipalities in South Africa still find it difficult to achieve their procurement objectives due to four major inundations; namely, the lack of training, the lack of capacity, the lack of transparency and the failure to comply with existing public procurement policies. The study recommends strategies for addressing the identified performance shortfalls in the area of municipal procurement.
\end{abstract}

Keywords: Procurement Challenges; Procurement Practices; Municipalities; South Africa

\section{INTRODUCTION AND BACKGROUND}

n most countries today, public procurement has emerged as a topic of intense public scrutiny as well as debate and has been subjected to a plethora of reforms, restructuring, rules and regulations (Williams \& Quinot 2007). In developing countries, public procurement is increasingly recognised as essential in service delivery and it accounts for a high proportion of total expenditure (Basheka \& Bisangabasaija, 2010). For the government to fulfil needs and satisfy their citizenry they are required to perform different functions, with procurement being one of the major activities. Watermeyer (2000) acknowledges that public procurement is often used by governments to stimulate economic activity, protect national industry against foreign competition, improve the competitiveness of certain industrial sectors and provide a remedy for regional disparities. Bolton (2006a) substantiates that public procurement is an important item of public expenditure with far-reaching social, economic and political implications. Public procurement is seen as one of the major instruments of government policy that can be used to improve social and economic development (Sahle, 2002). This indicates the fundamental role of public procurement in society, where it can be regarded as a business tool that has the primary intent of improving and sustaining better livelihoods for the entire citizenry of a particular country.

Since the rise of democracy in 1994 the South African government has been placed under pressure to correct the socio-economic imbalances resulting from many decades of apartheid. This has had the effect of increasing the government's determination to use public procurement as a means to reduce these imbalances (Bolton, 2006b). It is noteworthy that this will not happen overnight but it will take years of hard work to adjust these imbalances. Since municipalities in South Africa fall under the local government, they too are governed through public procurement frameworks enacted and enforced by government. The South African government realised the need to adopt an integrated approach towards public procurement of goods and services, which is encapsulated in the Preferential Procurement Policy Framework Act 05 of 2000. The objective of the Act is to give effect to section 217(3) of the Constitution of South Africa (Act 108 of 1996), which states, in part, that each 
municipality has a right to develop its own procurement policy and that the national legislation must prescribe a framework within which the procurement policy may be implemented.

Watermeyer (2003) defines procurement as the process that creates, manages and fulfils contracts relating to the provision of supplies, services or engineering and construction works, the disposal of property, the hiring of anything and the acquisition or granting of any right or concessions. Public procurement itself refers to the government activity of purchasing the goods and services needed to perform its functions. Arrowsmith (2010) defines procurement as a tool through which a client acquires services from a service provider with procurement documents, which defines the roles and responsibilities of both parties. In the context of this study, public procurement is narrowed down to the purchasing by a municipality of the goods and services it requires to function and to pursue public welfare (Williams, 2007). This lies at the heart of the development process and is therefore crucial to its effective, efficient and successful implementation.

As stated before, public procurement is seen as one of the instruments of government policy that can be used to improve social and economic development. It has been employed to achieve more direct social objectives, such as the creation of jobs, promotion of fair labour conditions, promotion of the use of local labour as a means to prevent discrimination against minority groups, protect the environment, encourage equality of opportunity between men and women, and promote the increased utilisation of the disabled in employment (Bolton, 2006a). Rogerson (2004) concurs that public procurement provides business and employment opportunities, and, depending on how it is structured, it can be used as an instrument to facilitate social and economic development. Magoro and Brynard (2010) further state that procurement policy is viewed as a possible source of job creation and increased utilisation of local labour. According to Watermeyer (2003), the United Nations Commission for the International Trade Law's Model Procurement of Goods, Construction and Services (UNCITRAL, 1995) points to the following as the objectives of public procurement:

- $\quad$ Maximizing economy and efficiency in procurement

- Fostering and encouraging participation in procurement proceedings by suppliers and contractors, especially where appropriate, and participation by suppliers and contractors regardless of nationality, and thereby promoting international trade

- $\quad$ Promoting competition among suppliers and contractors for the supply of goods, construction or services to be procured

- $\quad$ Providing fair and equitable treatment of all suppliers and contractors

- $\quad$ Promoting the integrity of and fairness and public confidence in the procurement process

- $\quad$ Achieving transparency in the procedures relating to procurement

The above-stated objectives of public procurement are achieved through various means and legal and regulatory rules on conducting public procurement (Arrowsmith, 2010). Procurement is therefore a valid and valuable tool for the implementation of social policies, which should not be denied to government(s) without convincing justification (Arrowsmith, 2010).

In South Africa, public procurement policies are structured to promote economic reconciliation and competitiveness (Rogerson, 2004). The government intends to use the preferential procurement policy framework to achieve its socio-economic objectives which include the development of small, medium and micro enterprises, particularly those owned and operated by previously disadvantaged individuals (Ambe \& Badenhorst-Weiss, 2012). The procurement framework is tailored to achieve the five principles of public procurement which include fairness, transparency, competitiveness, equitableness and cost-effectiveness (Pauw \& Wolraardt, 2009). The policy can also be used in the acceleration of the rate at which work is made available to the poor, as well as the generation of income within marginalised sectors of the economy, and the adherence to affirmative action to counteract the deliberate marginalisation of black people, women and rural communities along economic, political and social lines (Deloitte, 2013).

Municipalities have an important role to play in assisting government in achieving its predetermined socioeconomic objectives through procurement (Watermeyer, Gounden, Leitchmiah \& Shezi, 1998). According to Watermeyer (2003), several methods can be used in the implementation of preferential procurement policy which, if 
followed correctly, can enable municipalities to achieve their socio-economic objectives. A municipality is defined in sections 2b (i) and (ii) of the Municipal System Act (2000) as an entity that consists of an administration, a political structure and the community in a determined area. South African municipalities are subject to the Municipal Finance Management Act, 2003 (MFMA), which became effective in July 2004. The MFMA is an extension of the Public Finance Management Act. The main objective of the MFMA is to secure sound and sustainable management of the fiscal and financial affairs of municipalities by establishing norms and standards and other requirements for, among other things, supply chain management. Furthermore, the MFMA is also meant to promote the ethical behaviour of officials involved in public procurement (Act 56 of 2003). This framework is therefore aligned to the objectives of the mainstream preferential procurement policy framework, and also serves to ensure that economic and social benefits associated with public procurement cascade down to municipal constituencies.

\section{PROBLEM STATEMENT}

Municipalities still face a number of problems when it comes to public procurement (Ambe \& BadenhorstWeiss 2012). As such, although procurement is an important business function in municipal operations, its objectives are yet to be completely achieved within South African municipalities. Municipalities in South Africa encounter challenges that include insufficient budgets, capacity and equipment, which makes it difficult for them to implement and follow procurement policies as stipulated in the constitution (Godfrey \& Oelofse, 2008). Despite these handicaps, municipalities are still expected to assume greater responsibility for a growing range of programmes without receiving additional resources from national or provincial government (Centre for Development and Enterprise, 2003). However, if implemented with precision, the municipal procurement system has the potential to assist in achieving goals related to local economic development, including poverty reduction (Rogerson, 2004).

It is against this backdrop that this study sought to examine strategies that may enhance the effectiveness of procurement practices in municipalities in Gauteng Province, South Africa. As the micro and macro-economic environments under which municipalities operate continue to change, municipalities are faced with the task of ensuring that their operations adapt to these changes by implementing strategies that are tailor-made to ensure success (Raythorne, 2003). Parnell and Pieterse (2002) argue that the "fragmented" nature of local government inherited from apartheid is a major obstacle to the effective design of indigent support in South African cities. This study aims to offer a contemporary perspective of the procurement challenges faced by municipalities and recommends a sustainable way forward. Supply chain managers in municipalities may use the findings of this study as a useful source of information for enhancing the effectiveness of municipal procurement operations, which contributes to improving the overall performance of municipalities. This study is qualitative in nature, which offers a renewed but more in-depth perspective of this issue. Therefore, the purpose of the study is to investigate the procurement challenges faced by municipalities in South Africa.

\section{RESEARCH METHODOLOGY}

A literature study on procurement practices within district and local municipalities was conducted. The study used a wide range of materials including textbooks, journal articles, conference papers as well as Internet sources.

For the purposes of conducting the empirical portion of the study, a qualitative research design was adopted. Qualitative research involves the collection, analysis, and interpretation of data that are not easily reduced to numbers (Anderson, 2010). This method was chosen because it is more appropriate for obtaining accurate information needed for this study since it ensures that the data collected directly relates to the objectives of the study (Petty, Thomson \& Stew 2012). More precisely, in the context of this study, a qualitative approach facilitated a deeper understanding of the strategies currently employed by municipalities in improving the effectiveness of public procurement. 


\section{Participants}

The target population was composed of supply chain practitioners as well as supply chain directors of municipalities in Gauteng, South Africa. The sampling frame was obtained from a list of twelve municipalities located in Gauteng, South Africa. Participants were selected using the non-probability purposive sampling technique. As suggested by Welman, Kruger and Mitchell (2005) purposive sampling involves selecting units (e.g individuals, groups of individuals, institutions) based on specific purposes associated with answering a research question. This ensures that only those entities that are of material value to the study are selected as participants (Teddlie \& Yu, 2007). Based on this prescription, the individuals selected to participate in this study were employed as supply chain managers in municipalities in Gauteng Province.

Among the 12 municipalities in Gauteng Province (South African Municipal Directory, 2007), 11 were covered in the current research study. An analysis of the major characteristics of the participants reveals that two participants were employed as supply chain managers, two participants were employed as assistant supply chain managers, and three were procurement managers and four were supply chain directors in their municipalities. Seven of the participants were male. Six of the participants were holders of at least a master's degree and the remaining five participants were holders of honour's degrees. All participants had been employed in their current positions for at least three years.

\section{Procedures for Data Collection}

Since a qualitative design was adopted for the study, primary data were collected using semi-structured interviews. Semi-structured interviews were considered appropriate for this study because they allow for probing of views and opinions where it is desirable for respondents to expand their answers, which make them a versatile method of collecting data (Gray, 2009). Accordingly, an interview guide/schedule was developed which covered the following six aspects that are considered critical to municipal procurement;

- Implementation of procurement policies within municipalities

- $\quad$ Difficult aspects of procurement policies

- $\quad$ Transparency of the procurement process

- $\quad$ Competition amongst suppliers

- $\quad$ Effectiveness of the procurement process

- Ways of improving the current procurement system and system

The interviews were held at designated sites after an informed consent and permission from the key stakeholders had been obtained. Due to the busy work schedules of the participants, each interview ran for periods ranging between 20 minutes to half an hour. All interviews were recoded using a digital voice recorder, in line with the prescription by Lee \& Lings (2008).

\section{Data analysis}

A trained professional was employed to transcribe the collected data from the voice format to text, as recommended by Kvale and Brinkmann (2009). Thereafter, the interview transcripts were read though a number of times in order to draw the key points and themes emanating therein, in a process known as content analysis (Zhang \& Wildemuth 2009). As defined by Hsieh and Shannon (2005), qualitative content analysis is a research method for the subjective interpretation of the content of text data through the systematic classification process of coding and identifying themes or patterns. As such, the researchers read and reflected upon the data transcripts a number of times until a point of saturation was reached. The point of saturation is that interval where themes begin to appear repeatedly (Maxwell, 2005). Thereafter, the themes were grouped into more manageable groups of sub-themes, after which a summary table of the main themes deriving from the participants' story were drawn up (Thorpe \& Holt, 2008). It is from these themes that conclusions and recommendations shall be drawn. 


\section{Measures of trustworthiness}

In qualitative research, trustworthiness relates to the validity and credibility of information provided to an enquirer (Roberts \& Priest, 2006). Maxwell's (2005) four indices of trustworthiness; namely, credibility, confirmability, transferability and dependability, were used to ascertain trustworthiness in the study.

To ensure credibility in the study, participants were selected using the purposive sampling approach, which ensured that only those individuals who serve the objectives of the study were selected as participants (Shenton, 2004). Additionally, all participants were made aware of the aims and importance of this research at the introductory stage of the interview so that they could answer the questions to the best of their abilities.

To ensure confirmability in the study, an audit trail was completed throughout the study to demonstrate how each decision was made. For instance, after all interviews, the researcher sent the transcripts to all selected participants via e-mail to assure and confirm the trustworthiness of the study as well as to thank them for their time, effort and valuable contribution they made to the study. This confirmation by the participants ensured that statements provide tacit assumptions of authenticity, objectivity and accuracy to substantiate validity and reliability (Roberts \& Priest, 2006).

Transferability was ascertained through noting the specific details of the research situation and methods, and comparing them to similar situations in other municipalities elsewhere (Lee \& Lings, 2008). In this case, the specifics between municipalities in Gauteng and other provinces in South Africa were considered comparable, which attests to the transferability of the results of this study to other contexts within South Africa and beyond.

Dependability or reliability relates to how well a researcher can assure readers of his/her findings and the way he/she arrived at them from the raw social context (Corbin \& Strauss, 2008). In this study, dependability was ascertained through triangulation, which relates to collecting data from two or more sources in order to achieve a comprehensive picture of a fixed point of reference (Padgett, 2008). In this study triangulation was obtained by using the data collected from interviews with participants from eleven different municipalities.

\section{RESEARCH RESULTS}

\section{Themes Emerging from the Interviews}

After analysing the collected data, the following four themes emerged:

1. Lack of effective training;

2. $\quad$ Lack of capacity;

3. $\quad$ Lack of transparency;

4. Failure to comply with procurement policies.

\section{Lack Of Effective Training}

The lack of effective knowledge, which is based on a deficiency of training, emerged as one of the major themes because many employees in supply chain departments within municipalities do not seem to have the knowledge of the preferential procurement framework as well the skills pertaining to the dynamics involved in modern public procurement operations. These insights are captured in the following except from one of the participants:

"We need trained people, because if people are trained, they are able to work faster. If they're not trained they make mistakes and it takes double the time to correct these mistakes and to do it right the first time. If you do it right the first time, you don't have to correct it. So I'd say that it is necessary to recruit a good complement of properly qualified staff and to continue with our training, since this is very important for eliminating backlogs. If you've got your staff trained then that speed and effectiveness will improve. This is one of the problems we are facing. People must be trained in order to enhance their skills" 
The lack of training amongst municipal employees has led to serious challenges regarding the implementation of any new procurement regulations by municipalities. For instance, the preferential procurement framework continues to change as it is modified regularly by the Department of Trade and Industry. However most supply chain practitioners in government are yet to receive formal training on some of these frequent changes and their implications for municipal practice. Another participant mentioned that municipalities need project managers who possess the knowledge of procurement because they sometimes encounter instances where one experienced individual is faced with ten projects, which creates a serious problem. Under such circumstances, most projects tend to fall behind, which has negative implications for service delivery.

Municipal procurement objectives can be met if effective training can be provided and prioritised within the public sector. In support of this notion, Section $119(1-3)$ of the Government Gazette, Volume 530, No. 32489 also emphasises the competency of officials involved in municipal supply chain management as stated below:

- The accounting officer and all other officials of a municipality or municipal entity involved in the implementation of the supply chain management policy of the municipality or municipal entity must meet the prescribed competency levels.

- A municipality and a municipal entity must, for the purposes of subsection (1), provide resources or opportunities for the training of officials referred to in that subsection to meet the prescribed competency levels.

- The National Treasury or a provincial treasury may assist municipalities and municipal entities in the training of officials referred to in subsection (1).

Although training has been given major emphases by the South African National Treasury as highlighted before, the results of the study as demonstrated by the existence of manifold performance shortfalls within supply chain departments reveal that current training efforts are ineffective. It may be necessary then to initiate a training plan in order to identify the loopholes and fill the gaps that exist within municipalities. To achieve this, a proper analysis of the organisation's training needs and skills in the form of a skills audit is a vital step in the process of developing a comprehensive training plan (Opperman \& Meyer, 2008). In that way, municipalities may be able to implement training programs to effectively reduce the performance gaps that currently exist amongst their supply chain management personnel.

\section{Lack of Capacity}

The lack of capacity emerged as a major and common challenge faced by supply chain management departments. The following except from one of the participants expresses this view:

"Some municipal departments they don't have the requisite technical skills and as a result we have to rely on external service providers such as consultants to come and assist and that itself delays the completion of tender processes because it implies that the implementation of some procurement activities has to de belayed until external expertise has been acquired. It is only after this has been achieved can the process of procurement proceed, and so I admit that this area where we are still experiencing a lot of challenges"

Another participant highlighted that his department was severely understaffed, as captured below:

"I need more staff. I should have at least fourteen people but currently I have five. Therefore, I am understaffed but the reason for this could be that I only started here last year April and I checked the establishment and observed that there's no way that I could work like that. I had to review the structure and everything; I had to go to the council for them to approve my request for more staff members. The approval only got through recently and so the job specifications are already out for advertisement. So yes, I have to get more staff as it affects our service delivery."

The lack of capacity has an adverse impact on municipal procurement activities. One participant mentioned that the effect of the lack of capacity is that most municipalities are unable to spend their budgets on time, especially their capital infrastructure budgets, which effectively results in spill overs, a situation that has negative ramifications 
for service delivery. Furthermore, although municipalities are expected to adhere to their annual procurement plans, poor procurement planning from the mainstream government subjects municipalities to supply chain management complications. For example, municipalities receive their budgets as a grant from the mainstream government. However, most of these grants are received late into the financial year, thereby delaying the entire municipal procurement processes and interrupting the delivery of some services. The rationale in this instance is that the government is responsible for all services that are rendered to communities such that its failure to effectively allocate budgets means that the all-inclusive procurement process will also be a failure.

According to Deloitte (2013), the skills and capacity challenges are symptoms of the underlying human resource management inefficiencies in municipalities. They also represent an opportunity for the local government with the support of national and provincial government to revamp their entire human resource value chain and employee value proposition (Parliamentary Monitoring Group, 2010). It appears important then to address capacity constraints emanating from the apparently inadequate skills base, the lack of career modelling, the lack of skills development programmes and under-investment in technical, management and leadership skills (McCrudden, 1999). A commitment to these issues could trigger substantive improvements in municipal procurement operations in South Africa.

\section{Lack of Transparency}

Transparency is arguably one of the most important ethical principles in any procurement system (Morris, 1998). In fact, it is identified by Raythorne (2003) as one of the core principles of high quality public procurement. The public procurement policy in South Africa stipulates that procurement must be fair, transparent, equitable and competitive (Municipal System Act, 2000). Transparency may be interpreted as involving publicised contracts, disclosure of the rules governing procurement in general and governing specific procurements, rule-based decision making and opportunities for verification and enforcement (Williams \& Quinot, 2007). The lack of transparency is a major stumbling block to fairness, equal treatment and integrity in public procurement (Haque, 2013). Ensuring transparency in the procurement process is an essential determinant of the efficiency as it enhances the competitiveness of public procurement (Ohashi, 2006). It is therefore critical for municipalities to ensure transparency throughout the tender process.

Municipalities are required by the government to ensure that their procurement processes are transparent in every possible way. However, in this study it was observed that the lack of transparency is a major hindrance to the procurement system within municipalities. Issues that arose include the lack of information accessibility as well as lack of communication with regards to giving feedback to bidders after the tender application. Some participants strongly believe that it is very important for municipalities to revisit losing bidders and give them information regarding the reasons behind their failure to be awarded the tenders. One participant mentioned that he is working on a plan of having a well-designed website which will contain all the information that communities may need with regard to municipal procurement. The participant also admitted that his municipality is lagging behind in terms of transparency although plans have been put in place to turn around the situation. Despite this, most participants indicated that they are aware of the importance of transparency in procurement and its impact in the entire public procurement process. It appears then that municipalities in South Africa need to generate holistic solutions that ensure that transparency is embedded in all supply chain activities.

\section{4. $\quad$ Failure to Comply with Procurement Regulations}

Compliance with existing policies emerged as a serious concern in the study, particularly with regards to the use of supplier databases for the purposes of municipal procurement. According to one participant, the current procurement policy stipulates that suppliers have to register on the database of municipalities they intend to service. However, despite the fact that most suppliers managed to register, a majority of the municipalities appear to be failing to make use of their supplier databases. The following quotation from another participant highlights this standpoint: 
"My municipality does not use a suppliers' database at all because the computer software installed in the department is very difficult to use and everyone is avoiding it. If this matter can be sorted out, they can actually promote the distribution of work by rotating through the database"

Another participant admitted that they are not doing anything to encourage competition. This participant pointed out that her municipality is not complying with the policy, as conveyed through the following citation:

"We have a supplier database but that's up to thirty thousand. Unfortunately there I can maybe say we are not really following the system. In other words, people who work at the stores tend to know which one among their supplier performs well and is able to meet delivery schedules. If you fax an order to a particular supplier, they will later claim that they never received the order and then they may indicate that they cannot deliver because their vehicle broke down. So yes unfortunately, I must say that I think we are biased towards those suppliers that we already trust. A data base is therefore not the best source of supplier information to us"

Another concern with regard to compliance relates to prices of goods and service procured by municipalities. The Municipal System Act (2000) prescribes that municipalities have a limit that they must adhere to in terms of percentages such that suppliers who quote above that percentage should not be awarded any tenders. However, a surprising and growing tendency within municipalities is that numerous suppliers who quote above the stipulated price are awarded tenders, in contravention of the existing public procurement policies. The following excerpt from one participant captures this observation:

"There's that particular understanding out there that if you are tendering for the government you can sell a loaf of bread for 50 rand whereas a loaf of bread should ordinarily cost 12 rand."

Another participant added:

"According to our policy we need to give all suppliers a chance but you find that some suppliers' prices are ridiculous which naturally makes it very difficult to buy from them. Surprisingly, these high price suppliers are getting more tenders these days"

As substantiated by Stevenson (2009), maintaining compliance with positive and relevant policies is increasingly being recognised as a critical factor in sustaining a competitive advantage. However, it appears that compliance with pricing regulations remains a serious challenge for municipalities as far as compliance is concerned.

\section{CONCLUSIONS AND RECOMMENDATIONS}

The aim of this study was to investigate the challenges faced by municipalities in South Africa in their procurement activities. The findings of the study revealed four major challenges; namely the lack of training, the lack of capacity, the lack of transparency and the failure to comply with existing public procurement policies, which continue to militate procurement activities in municipalities.

In order to address the challenges identified in the study, several recommendations are put forward. First, it is necessary to upgrade the skills and competency levels of staff in supply chain departments in municipalities. This could be achieved through the implementation of sustained staff training programs which are supported by the recruitment of adequately skilled supply chain practitioners (Armstrong, 2001). Municipalities should continue to lobby the government for the improvement of their capacities and infrastructure. Issues that should be considered include the improvement of the coordination and impact of support, capacity building and training, improved municipal individual capacity, improved municipal institutional/environmental capacity and the linkage of municipal capacity issues to the community (Ambe \& Badenhorst-Weiss, 2011). Greater standardisation of procurement policies may be considered, as this is likely to enhance the public accessibility to information and improve monitoring and oversight, thereby addressing current inundations related to transparency and compliance (Schulz-Herzenberg, Mukadam \& Felton, 2011). Furthermore, the centralisation of procurement functions should be implemented within municipalities to reduce costs. Centralisation offers a number of advantages, such as leverage 
due to volumes, reduction of duplication of purchasing effort, better control and development of specialised expertise (Handfield, Monczka, Guinipero \& Patterson, 2011). These mechanisms may prove to be indispensible instruments in addressing the municipal procurement challenges identified in this study.

\section{LIMITATIONS AND IMPLICATIONS FOR FUTURE RESEARCH}

The value of the study lies in its purposive sample, which ensured that the data was elicited only from individuals that had a clear understanding and knowledge of municipal procurement processes. This aspect adds to the credibility of the findings. Be that as it may, the study is limited in that only four challenges were identified. It is possible that some participants were afraid of exposing some of the more sensitive issues pertaining to municipal procurement, for fear of victimisation. In view of this, future research should be tailored to unearth other challenges that the present study could not identify. Since this study used a qualitative approach, future research could be conducted using the mixed method approach. Future studies on the same topic may also be conducted in other provinces of South Africa. This may provide a basis for comparing the findings of studies conducted in the various provinces. Longitudinal studies in the same province using the same municipalities could be conducted so that the changes in procurement challenges in municipalities can be captured at different points in time. Since the current study used a sample of senior municipal officials, future studies could include the views of lower ranking employees who have more information on municipal supply chain operations at base level.

\section{REFERENCES}

1. Ambe, I.M., \& Badenhorst-Weiss, J.A. (2011). An exploration of public sector supply chains with specific reference to the South African situation. Journal of Public Administration, 46(3), 1100-1115.

2. Ambe, I.M., \& Badenhorst-Weiss, J.A. (2012). Procurement challenges in the South African public sector. Journal of Transport and Supply Chain Management, 6(1), 242-261.

3. Anderson, C. (2010). Presenting and evaluating qualitative research. American Journal of Pharmaceutical Education, 74(8), 1-7.

4. Armstrong, M.J. (2001). A handbook of personnel management practice. London: Kogan Page.

5. Arrowsmith, S. (2010). Public procurement: basic concepts and the coverage of procurement rules. In Public procurement relations: an introduction. EU Asia Inter University Network.

6. Bolton, P. (2006a). Government procurement as a policy tool in South Africa: Journal of Public Procurement, 6(3), 193-217.

7. Bolton, P. (2006b). Grounds for dispensing with public tender procedures in Government contracting. Potchefstroom Electronic Law Journal, 9(2), 1-38.

8. Basheka, B. C., \& Bisangabasaija, E. (2010). Determinants of unethical public procurement in local government systems of Uganda: a case study. International Journal of Procurement Management 3(1), 91 104.

9. Centre for Development \& Enterprise (CDE). (2003). Informing South African Policy. Local government in South Africa: Priorities for action. Media Releases.

10. Corbin, J., \& Strauss, A. (2008). Basics of qualitative research. $3^{\text {rd }}$ ed. Thousand Oaks (CA): Sage.

11. Deloitte (2013). Municipal clean audit: thought leadership series- skills and capacity challenges. Retrieved January 21, 2014 from: http://www.deloitte.com/assets/DcomSouthAfrica/Local\%20Assets/Documents/Deloitte_Municipal_Clean_Audit_Series3.pdf.

12. Godfrey, L., \& Oelofse, S. (2008). A system approach to waste governance - unpacking the challenges facing local government: CSIR, Natural Resources and the Environment (NRE): Pretoria.

13. Gray, D.E. (2009). Doing research in the real world. $2^{\text {nd }}$ ed. Thousand Oaks (CA): Sage.

14. Handfield, R.B., Monczka, R.M., Guinipero, L.C., \& Patterson, J.L. (2011). Sourcing and supply chain management. USA. $5^{\text {th }}$ Ed. South Western Cengage Learning.

15. Haque, K. (2013). Increasing transparency and accountability in municipal public procurement through citizen engagement. Policy note: Brac University.

16. Hsieh, H.F., \& Shannon, S.E. (2005). Three approaches to qualitative content analysis. Qualitative Health Research, 15(9), 1277-1288.

17. Kvale, S., \& Brinkmann, S. (2009). Interviews: learning the craft of qualitative research interviewing. $2^{\text {nd }}$ ed. Thousand Oaks (CA): Sage. 
18. Lee, N., \& Lings, I. (2008). Doing business research: a guide to theory and practice. Thousand Oaks (CA): Sage.

19. Magoro, M.J., \& Brynard, P.A. (2010). Difficulties associated with the implementation of the preferential procurement policy in conjunction with a low-cost housing programme: a South African contextualization, Politeia, 29(3), 4-23.

20. Maxwell, J. A. (2005). Qualitative research design: an interpretive approach. $2^{\text {nd }}$ ed. Thousand Oaks (CA): Sage.

21. McCrudden, C. (1999). International economic law and the pursuit of human rights: a framework for discussion of the legality of 'selective purchasing' laws under the WTO Government Procurement Agreement. Journal of International Economic Law, 2 (1): 3-48.

22. Morris, P.E .(1998). Legal regulation of contract compliance: an Anglo American comparison. Anglo American Law Review, 19:87-144.

23. Ohashi, H. (2006). Effects of transparency in procurement practices on government expenditure: a case study of municipal public works.Department of Economics, University of Tokyo: Tokyo

24. Opperman, C. \& Meyer, M. (2008). Integrating training needs analysis, assessment and evaluation: aligning learning with business results. Johannesburg: Knowres Publishing.

25. Padgett, D. (2008). Qualitative methods in social work research. Los Angeles: Sage Publications.

26. Parliamentary Monitoring Group. (2010). Capacity building at municipalities: National Treasury, DBSA, Department Cooperative Governance \& Traditional Affairs \& SALGA briefings. Committee meeting, 16 August 2010.

27. Parnell, S., \& Pieterse, E. (2002). Developmental local government. In Parnell, S et al., (Eds.), Democratising Local Government: the South African Experiment. UCT Press, Cape Town.

28. Pauw, J.C. \& Wolvaardt, J.S. (2009). Multi-criteria decision analysis in public procurement - a plan from the South. Politeia, 28 (1): 66-88.

29. Petty, N.J, Thomson, O.P., \& Stew, G. (2012). Ready for a paradigm shift? Part 1: introducing the philosophy of qualitative research. Manual Therapy, 17, 267-274.

30. Raythorne, D.L. (2003). Municipal Administration. Lansdowne: Juta \& Co. Ltd.

31. Republic of South Africa. (2012). MFMA Circular No. 66. Municipal Finance Management Act No. 56 of 2003 Municipal Budget Circular for the 2013/14 MTREF (1-27).

32. Republic of South Africa. (2000). Municipal System Act (Act 32 of 2000).

33. Republic of South Africa. (2000). Preferential Procurement Policy Framework Act (Act 5 of 2000).

34. Republic of South Africa. (1996). The Constitution of South Africa (Act 108 of 1996). Pretoria: Government printers.

35. Roberts, P., \& Priest, H. (2006). Reliability and validity in research. Nursing Standard, 20(44), 41-45.

36. Rogerson, C.M. (2004). Pro-poor local economic development in South Africa: the application of Public Procurement. Urban Forum, 12(2), 180-210.

37. Sahle, D. (2002). Procurement: a tool to address key development and social issues. Asist Bulletin 14(1), September, ILO/ASIST.

38. Schulz-Herzenberg, C. Mukadam, S., \& Felton, J. (2011). Implementing financial disclosure in local government: content, scope and standardisation. Knowledge empowers Africa: Policy Brief Number 27 , November 2011. Pretoria, South Africa.

39. Shenton, A.K. (2004). Strategies for ensuring trustworthiness in qualitative research projects. Education for Information, 22(4), 63-75.

40. South African Municipal and Government Directory. (2007). SADC: Johannesburg.

41. Stevenson, W.J. (2009). Operations management, $10^{\text {th }}$ ed. McGraw-Hill: Boston.

42. Teddlie, C., \& Yu, F. (2007). Mixed methods sampling: a typology with examples. Journal of Mixed Methods Research: 21(1), 77-100.

43. Thorpe, R. \& Holt, R. (2008). The dictionary of qualitative research. London: Sage.

44. United Nations Commission for International Trade Law (UNCITRAL). (1995). Model law on procurement of goods, construction and services. New York: United Nations.

45. Watermeyer, R.B. (2000). The use of targeted procurement as an instrument of poverty alleviation and job creation in infrastructure projects: public procurement. Law Review 5(1), 226-250.

46. Watermeyer, R.B. (2003). Implementing preferential procurement policies in the public sector in S.A. Journal of the South African Institution of Civil Engineering, 45(3), 11-22. 
47. Watermeyer, R.B., Gounden, S.M., Leitchmiah, D.R., \& Shezi, S. (1998). Targeted procurement: a means by which socio-economic objectives can be realized through engineering and construction works contracts. SAICE 40(4), 15-25.

48. Welman, J.C., Kruger, S.J., \& Mitchell, B.C. (2005). Research methodology. $3^{\text {rd }}$ ed. Cape Town: Oxford University Press.

49. Williams, S. (2007). Public procurement and corruption: the South African response. The South African Law Journal, 124(2), 339-363.

50. Williams, S., \& Quinot, G. (2007). Public Procurement and Corruption: The South African Response. University of Stellenbosch. South African Law Journal, 12(4), 339-363.

51. Zhang, Y., \& Wildemuth, B. M. (2009). Qualitative analysis of content: applications of social research methods to questions in Information and Library Science. Libraries Unlimited: Westport, CT. 
NOTES 